Published by Ikatan Sarjana Gizi Indonesia (ISAGI) - The Indonesian Nutrition Scholars Association

\title{
An Obesvational Study of Knowledge and Attitudes of Balanced Nutrition and Nutritional Status among High School Students in Bekasi City, Indonesia
}

\section{STUDI OBSERVASI PENGETAHUAN DAN SIKAP GIZI SEIMBANG DAN STATUS GIZI SISWA SMA DI KOTA BEKASI, INDONESIA}

\author{
Muhammad Nur Hasan Syah ${ }^{*}$, Ika Wirya Wirawanti2 \\ ${ }^{1}$ Nutrition Study Program, Universitas Pembangunan Nasional Veteran, Jakarta, Indonesia \\ ${ }^{2}$ Nutrition Study Program, Universitas Megarezky, Makassar, Indonesia \\ * Email corresponding author: mnhasansyah@upnvj.ac.id
}

\begin{abstract}
Nutrition problems in adolescents are influenced by various factors, one of the factors is the lack of promotion of balanced nutrition guidelines application. The application of balanced nutrition guidelines is influenced by knowledge and attitudes about the message of balanced nutrition guidelines. This study aimed to determine the relationship between knowledge and attitudes of balanced nutrition with nutritional status among adolescents. The type of this study was quantitative with a cross-sectional design, and the respondents were students of SMAN 1 Bekasi (16-18 years old). The independent variables of this study were knowledge and attitudes about balanced nutrition, and the dependent variable was nutritional status. The data were collected using a questionnaire about knowledge and attitudes of balanced nutrition and analyzed using the Fisher test. The results showed that there was a relationship between knowledge about balanced nutrition with nutritional status among adolescents in SMAN 1 Bekasi with a $p$-value of 0,040 $(p<0,05)$, and also there was a relationship between the attitudes about balanced nutrition with nutritional status among adolescents in SMAN 1 Bekasi with p-value $0,002(p<0,05)$. The conclusion was there was a relationship between knowledge and attitudes of balanced nutrition with nutritional status among adolescents in SMAN 1 Bekasi.
\end{abstract}

Keywords: adolescent, attitudes, balanced nutrition, knowledge, nutritional status

\section{INTRODUCTION}

Nutrition in adolescents is an investment for a nation because nutrition is one of the important things that determine the quality of each individual. Adolescents are a group that is very vulnerable to nutritional problems caused by several things, namely increased nutritional needs and lifestyle changes. According to WHO, adolescents are children aged 10-19 years. Adolescence is a transition from childhood to adulthood characterized by physical, psychological, and psychosocial changes (1). The process of growth and development still occurs in adolescents. Nutrients are one of the factors that influence the process so that it takes place optimally. Nutritional problems in adolescents are known as "double burden" nutritional problems, which means that malnutrition and overnutrition occur simultaneously. This double burden nutritional problem is one of the health problems of concern in Indonesia (2).

According to the basic health research data in 2013, the prevalence of underweight in adolescents aged 16-18 years was 1.9 percent, while overweight increased very significant from 2010, which was 7.3 percent. The same thing happened in Bekasi City, where nutritional problems were still relatively high. Nutritional problems in 
adolescents aged 16-18 years in Bekasi City according to the basic health research data for West Java in 2013 were underweight 9.1 percent, overweight 7.5 percent, and obese 4.5 percent (3). Because of the severe nutritional problems, every individual needs to know the principles of implementing a healthy lifestyle, one of them is to apply balanced nutrition guidelines. Balanced nutrition is a food composition that contains nutrients based on the body's needs of each individual, taking into account the principles of food diversity, physical activity, clean living behavior, and maintaining a normal body weight to prevent nutritional problems (4).

One of the factors that influence nutritional problems in adolescents is the lack of promotion of balanced nutrition guidelines (5). In adolescents, nutritional problems are caused by incorrect knowledge, attitudes, and nutritional behavior. There is an imbalance between the nutrients obtained from the consumption of food and beverages with the recommended nutritional adequacy. Knowledge of nutrition is a person's understanding of the science of nutrition and the interaction between nutrition and nutritional status and health, formed by the knowledge perceived as good or bad, then internalized into him. Knowledge of adolescent nutrition in students is still relatively low, so that attitudes towards healthy and nutritious food choices are still lacking (6). This shows that well-balanced nutrition knowledge can produce positive attitudes and behaviors towards balanced nutrition to improve nutritional status. This study aimed to determine the relationship between knowledge and attitudes about balanced nutrition with nutritional status among adolescents in SMAN 1 Bekasi.

\section{METHODS}

The type of this study was quantitative with a cross-sectional design. The study was conducted at SMAN 1 Bekasi. The sample in this study was adolescents in SMAN 1 Bekasi consisting of grade X and XI with 206 students who were taken by purposive sampling according to inclusion and exclusion criteria. The inclusion criteria were adolescents aged 16-18 years, students of class X and XI, and willing to participate in the study, while the exclusion criteria was students who did not participate in the study process as a whole. Knowledge and attitudes data were collected using a questionnaire about balanced nutrition, while nutritional status was collected through weighing using a weight scale and measuring height using a microtoice. Data was analyzed using the SPSS 18.00 program with the first stage was univariate analysis to see the distribution of respondent's characteristics and nutritional status, followed by bivariate analysis using Fisher's test to know the relationship between two variables with ordinal and nominal data scales. With this test, the study results showed whether there were a relationship between knowledge and attitude about balanced nutrition with nutritional status among adolescents in SMAN 1 Bekasi.

\section{RESULTS}

The results showed that the distribution of respondents' characteristics by gender were more in female, namely 151 students (73.3\%) compared to 55 female (26.7\%). According to age, most respondents were 16 years old, namely, 160 students (77.7\%), while respondents aged 17 years were 46 students (22.3\%). Nutritional status was categorized based on Body Mass Index by Age (BMI/U), grouped into three categories of nutritional status (7). The distribution of nutritional status showed that the majority of respondents had normal nutritional status, namely 157 students (76.2\%), while the underweight was 7 students (3.4\%) and overweight was 42 students (20.4\%). The distribution of gender, age, and nutritional status of respondents can be seen in Table 1. 
Table 1. The Distribution of Respondents Characteristics

\begin{tabular}{lcc}
\hline \multirow{2}{*}{ Characteristics } & \multicolumn{2}{c}{ Frequency } \\
\cline { 2 - 3 } Gender & $\mathrm{N}$ & $\%$ \\
Male & 55 & 26,7 \\
Female & 151 & 73,3 \\
\hline Total & 206 & 100 \\
\hline Age & & \\
16 Years & 160 & 77,7 \\
17 Years & 46 & 22,3 \\
\hline Total & 206 & 100 \\
\hline Nutritional Status & & \\
$\quad$ Underweight & 7 & 3,4 \\
Normal & 157 & 76,2 \\
$\quad$ Overweight & 42 & 20,4 \\
\hline Total & 206 & 100 \\
\hline
\end{tabular}

Based on data on the exposure of balanced nutrition on respondents, the results showed that the majority of respondents had never been exposed to balanced nutrition guidelines, namely 149 students (72.3\%), while only 57 students $(27.7 \%)$ had been exposed to balanced nutrition guidelines, which can be seen in Table 2.

Table 2. The Distribution of Exposure about Balanced Nutrition Guidelines on Respondents

\begin{tabular}{lcc}
\hline \multirow{2}{*}{ Exposure } & \multicolumn{3}{c}{ Frequency } \\
\cline { 2 - 3 } & $\mathrm{N}$ & $\%$ \\
\hline Yes & 57 & 27,7 \\
No & 149 & 72,3 \\
\hline Total & 206 & 100 \\
\hline
\end{tabular}

Data about the knowledge and attitudes about balanced nutrition of respondents can be seen in Table 3. Based on the results of the study, the average score of knowledge and attitudes about balanced nutrition of respondents showed that the median score of knowledge was 76 while attitudes was 80 , the standard deviation of knowledge was 11.7 while attitudes was 7.1 , the minimum score for knowledge was 20 while the attitudes was 59. The maximum score for knowledge was 96, and the attitudes was 98.

Table 3. The Distribution of Knowledge and Attitudes Scores about Balanced Nutrition on Respondents

\begin{tabular}{lcccc}
\hline \multicolumn{1}{c}{ Variables } & Median & SD & Min & Max \\
\hline Knowledge & 76 & 11,7 & 20 & 96 \\
Attitudes & 80 & 7,1 & 59 & 98 \\
\hline
\end{tabular}

The results regarding the level of knowledge and attitudes of respondents were obtained through a questionnaire and divided into two categories, which were knowledge was divided into sufficient and poor, while attitudes was divided into positive and negative. Data about knowledge and attitudes can be seen in Table 4. Table 4 showed that more than half of the respondents had sufficient knowledge, namely 150 students $(72.8 \%)$, while 56 students $(27.2 \%)$ had poor knowledge. For attitudes, as many as 189 students (91.7\%) of respondents had a positive attitudes about balanced nutrition, and 17 students (8.3\%) of respondents had a negative attitudes. 
Table 4. The Distribution of Knowledge and Attitudes about Balanced Nutrition on Respondents

\begin{tabular}{lcc}
\hline \multirow{2}{*}{ Variables } & \multicolumn{2}{c}{ Frequency } \\
\cline { 2 - 3 } & $\mathrm{N}$ & $\%$ \\
\hline Knowledge & 150 & 72,8 \\
Sufficient & 56 & 27,2 \\
$\quad$ Poor & 206 & 100 \\
\hline Total & 189 & \\
\hline Attitudes & 17 & 91,7 \\
Positive & 206 & 8,3 \\
$\quad$ Negative & & 100 \\
\hline Total & & \\
\hline
\end{tabular}

The study results also showed the total respondents based on nutritional status according to the level of knowledge and attitudes. The data can be seen in Table 5, which showed that respondents who had sufficient knowledge and had a positive attitudes about balanced nutrition was 145 students (96.6\%) and 112 students (77.2\%) had normal nutritional status, while the poor of knowledge but had a positive attitudes about balanced nutrition was 44 students $(78.5 \%)$ and 31 students $(70.5 \%)$ had normal nutritional status.

Table 5. The Distribution between Knowledge and Attitudes about Balanced Nutrition with Nutritional Status of Respondents

\begin{tabular}{|c|c|c|c|c|c|c|c|c|c|}
\hline \multirow{3}{*}{ Knowledge } & \multirow{3}{*}{ Attitudes } & \multicolumn{6}{|c|}{ Nutritional Status } & \multicolumn{2}{|c|}{ Total } \\
\hline & & \multicolumn{2}{|c|}{ Underweight } & \multicolumn{2}{|c|}{ Normal } & \multicolumn{2}{|c|}{ Overweight } & \multirow{2}{*}{$\mathrm{N}$} & \multirow{2}{*}{$\%$} \\
\hline & & $\mathrm{N}$ & $\%$ & $\mathrm{~N}$ & $\%$ & $\mathrm{~N}$ & $\%$ & & \\
\hline \multirow[t]{2}{*}{ Sufficient } & Positive & 1 & 0,7 & 112 & 77,2 & 32 & 22,1 & 145 & 100 \\
\hline & Negative & 1 & 20 & 4 & 80 & 0 & 0 & 5 & 100 \\
\hline \multirow[t]{2}{*}{ Poor } & Positive & 3 & 6,8 & 31 & 70,5 & 10 & 22,7 & 44 & 100 \\
\hline & Negative & 2 & 16,7 & 10 & 83,3 & 0 & 0 & 12 & 100 \\
\hline \multicolumn{2}{|c|}{ Total } & 7 & 3,4 & 157 & 76,2 & 42 & 20,4 & 206 & 100 \\
\hline
\end{tabular}

The relationship between knowledge and attitudes about balanced nutrition with nutritional status of respondents can be seen in Table 6, which showed that the p-values were respectively 0.040 and $0.002(\mathrm{p}<0.05)$, using Fisher's test. This showed a relationship between knowledge and attitudes about balanced nutrition with the nutritional status of the respondents. This relationship exists by following under the results of the distribution of respondents, the majority of whom were knowledgeable enough were 150 students (72.8\%) of the total respondents and 116 students $(77.3 \%)$ of whom had normal nutritional status while the distribution of respondents' attitudes were positive attitudes of 189 students $(91.7 \%)$ and 143 people $(69.42 \%)$ of whom had normal nutritional status. 
Table 6. The Relationship between Knowledge and Attitude about Balanced Nutrition with Nutritional Status of Respondents

\begin{tabular}{|c|c|c|c|c|c|c|c|c|c|}
\hline \multirow{3}{*}{ Variables } & \multicolumn{6}{|c|}{ Nutritional Status } & \multicolumn{2}{|c|}{ Total } & \multirow{3}{*}{$\begin{array}{c}\mathrm{P} \\
\text { Value }\end{array}$} \\
\hline & \multicolumn{2}{|c|}{ Underweight } & \multicolumn{2}{|c|}{ Normal } & \multicolumn{2}{|c|}{ Overweight } & \multirow{2}{*}{$\mathrm{N}$} & \multirow{2}{*}{$\%$} & \\
\hline & $\mathrm{N}$ & $\%$ & $\mathrm{~N}$ & $\%$ & $\mathrm{~N}$ & $\%$ & & & \\
\hline \multicolumn{10}{|l|}{ Knowledge } \\
\hline Sufficient & 2 & 1,33 & 116 & 77,3 & 32 & 21,3 & 150 & 100 & \multirow{3}{*}{0,04} \\
\hline Poor & 5 & 8,9 & 41 & 73,2 & 10 & 17,8 & 56 & 100 & \\
\hline Total & 7 & 3,4 & 157 & 76,2 & 42 & 20 & 206 & 100 & \\
\hline \multicolumn{9}{|l|}{ Attitudes } & \multirow{4}{*}{0,002} \\
\hline Positive & 4 & 12,1 & 143 & 75,6 & 42 & 22,2 & 189 & 100 & \\
\hline Negative & 3 & 17,6 & 14 & 82,3 & 0 & 0 & 17 & 100 & \\
\hline Total & 7 & 3,4 & 157 & 76,2 & 42 & 20,4 & 206 & 100 & \\
\hline
\end{tabular}

\section{DISCUSSION}

Based on this study results at SMAN 1 Bekasi, 76.2 percent of respondents had normal nutritional status, 20.4 percent of respondents were overweight, and 3.4 percent of respondents were underweight. The results of this study supported the basic health research data in 2013 which showed that the nutritional status of adolescents aged 16-18 years based on BMI/U in Bekasi City were 12 percent overweight and obese while underweight was 11.1 percent (3). Triwinarni's study (2017) on students in grades X and XI in four high schools in Pakem District shown that respondents with underweight nutrition were 5.2 percent and obese were 13.9 percent. Nutritional problems were not only found in Indonesia, other countries were still experiencing the same problem (8). The study of Awasthi, et al. (2016) on adolescent girls in Moradabad, India, found that the underweight was 15.6 percent and overweight was 3.5 percent (9). In addition to India, in a study in Mindanao, the Philippines, from 324 adolescents, 80.2 percent were found to be underweight and 4.9 percent were overweight. The results of the study implied that the problem of malnutrition was still very high in high school students, so it was important to address it immediately (10).

The majority of respondents in this study had sufficient knowledge, which were 72.8 percent, while those with poor knowledge were 27.2 percent. Various factors could influence nutrition knowledge. One of them was education. The higher the education, the more experienced and knowledge gained, and the wider knowledge (11). In this case, especially for students with education who had been exposed to balanced nutrition guidelines. In the study of Nurdzulqaidah, et al. (2018) for medical students at the Faculty of Medicine, Islamic University of Bandung, respondents with low knowledge were only 11.4 percent (12). A high percentage of low nutrition knowledge is also found in other countries. In the study of Shaziman, et al. (2017) in Selangor and Malaca, Malaysia, among 85 adolescents living in orphanages, most respondents had low knowledge of 83.5 percent (13). Al-Yateem's study (2017) on 300 teenagers in Sharjah, Arab found respondents with less knowledge as much as 85.3 percent (14). 
Based on the data obtained, almost respondents had a positive attitudes about balanced nutrition, namely 91.7 percent, while those with a negative attitudes were only 8.3 percent. Respondents with negative nutritional attitudes were also found in a study conducted by Salim (2013) on adolescents at Madrasah Aliyah Mamuju, where respondents who had negative attitudes were 3.7 percent (5). While in Arista's study (2017) on young women at the Baiturrahman Islamic Center Vocational High School Semarang, respondents with negative attitudes were 37 percent (15). The existence of a poor balanced nutrition attitudes was not only found in Indonesia but also in other countries. In Shaziman's study (2017) in Selangor and Malaca, Malaysia, on 85 adolescents, respondents who had poor nutritional attitudes were 32.9 percent (13).

The test results about the relationship between knowledge about balanced nutrition with nutritional status had p-value $0.046(\mathrm{p}<0.05)$. Knowledge about nutrition can affect a person's nutritional status because knowledge plays an important role in forming eating habits and influences a person in choosing the type and amount of food consumed. This was following the results of this study, which 77.3 percent of respondents with normal nutritional status had sufficient nutritional knowledge. Knowledge of nutrition-related to nutritional status was also in line with study conducted by Rizkiyanti (2015) on young women enrolled in the NLFC (Netic Ladies Futsal Bogor) and in Florence's study (2017) on students aged 17-19 years $(16,6)$. This is by following under the opinion of Maharibe (2013), which said that individuals who had good knowledge tend to pay more attention to the nutritional content of the food they consume to affect nutritional status. In this study, there were still respondents with sufficient knowledge but had nutritional problems, but there were also some respondents with less knowledge but had normal nutritional status. This could happen because it is related to a person's habits, there is the possibility of someone who has good knowledge, but the intake of nutrients is excessive or less than needed. Person who lack with nutritional knowledge but the intake of nutrients is sufficient according to their needs (17). Nutritional status is not only influenced by knowledge but also by other factors. Knowledge is not a direct cause of nutritional problems, where according to UNICEF theory, the direct causes of nutritional problems are food intake and infectious diseases (18).

A nutritional attitudes is a person's tendency to agree or disagree with a nutrition statement. Based on the test results, it was known that there was a relationship between balanced nutritional attitudes and nutritional status ( $p$ value $=0.002, p<0.05$ ). Based on the study results, 75.6 percent of respondents with normal nutritional status had a positive attitudes about balanced nutrition. This study was in line with study conducted by Salim (2013) at MAN Mamuju, which concluded that there was a relationship between attitudes about balanced nutrition and nutritional status. In this study, 91.1 percent of respondents with normal nutritional status had positive attitudes towards balanced nutrition (5). Siburian's study (2016) also showed a relationship between attitudes about balanced nutrition and nutritional status in adolescents at SMA 3 Singingi Hilir with p-value $=0.019$ (19). The attitudes of 
respondents in this study related to nutritional status could be influenced by the high knowledge of respondents about balanced nutrition. The initial formation of an attitudes is the knowledge that is perceived as a good or bad thing, then it is internalized into itself. This can be interpreted that good and bad attitudes towards nutrition are formed from the nutritional knowledge component. A person's knowledge can contain two aspects, namely positive and negative. These two aspects will determine a person's attitudes towards an object. The more positive aspects it will foster a positive attitudes towards the object (6). This was following by the results in this study which 96.6 percent of respondents with sufficient knowledge had a positive attitudes about nutrition, and 77.2 percent of them had normal nutritional status. This supported the study of Salsabilla (2017) on 58 students at SMKN 1 Kalasan Yogyakarta ehich showed that there was a relationship between nutritional knowledge and attitudes to eating healthy food with $r$ count $0.636>r$ table 0.29 . The higher the knowledge of nutrition, the higher the attitudes of consuming healthy food. On the contrary, the lower the knowledge, the lower the attitudes of consuming healthy food (20). This happens because the respondents had understood the benefits of nutrients for health. In this study, some respondents had positive attitudes about balanced nutrition but had nutritional problems, while there were respondents who had negative balanced nutrition attitudes but had normal nutritional status. This can happen due to various factors. According to Siburian (2016), a positive attitudes with abnormal nutritional status can be caused by family behavior that does not support and foster independence in overcoming nutritional problems, while a negative attitudes with normal nutritional status can be influenced by health services (primary health care facilities that are affordable by every family need) and an adequate environment (19).

\section{CONCLUSION}

The total of respondents in this study was 206 students. The majority of them, 76,2 percent, had normal nutritional status. Respondents with overweight nutritional status were 20.4 percent, and underweight were 3.4 percent. More than half of the respondents, 72.8 percent, had sufficient knowledge about balanced nutrition, while 27.2 percent had poor knowledge about balanced nutrition. Almost all respondents, 91.7 percent, had a positive attitudes about balanced nutrition and only 8.3 percent with negative attitude. The results of Fisher's Test showed that there were a relationship between knowledge and attitudes about balanced nutrition with the nutritional status of respondents with $\mathrm{p}$-values, respectively, 0.040 and $0.002(\mathrm{p}<0.05)$, which indicated that there was a relationship between knowledge and attitudes about balanced nutrition with nutritional status among adolescents in SMAN 1 Bekasi.

\section{REFERENCES}

1. Dieny, F., Fithra. (2014). Permasalahan gizi pada remaja putri. Yogyakarta: Graha Ilmu 
2. Suharidewi, I Gusti Dan Pinatih, GN. (2017). Gambaran Status Gizi pada Anak TK di Wilayah Kerja UPT Kesmas Blahbatuh II Kabupaten Gianyar Tahun 2015. E-Jurnal Medika. Vol. 6(6)

3. Kementerian Kesehatan RI. (2013). Riset Kesehatan Dasar. Jakarta: Kemenkes RI

4. Kementerian Kesehatan RI. (2014). Pedoman Gizi Seimbang. Jakarta: Kemenkes RI

5. Salim, A. (2013). Gambaran Perilaku Gizi Seimbang Terhadap Status Gizi Remaja Di Madrasah Aliyah Negeri Kabupaten Mamuju Tahun 2012. Jurusan Gizi, Politeknik Kesehatan Kemenkes, Mamuju. Jurnal Media Gizi Pangan. (Xv) Edisi 1

6. Florence, A. Grace. (2017). Hubungan Pengetahuan Gizi Dan Pola Konsumsi Dengan Status Gizi Pada Mahasiswa TPB Sekolah Bisnis Dan Manajemen Institut Teknologi Bandung. Skripsi. Program Studi Teknologi Pangan. Fakultas Teknik. Universitas Pasundan. Bandung

7. Kementerian Kesehatan RI. (2011). Standar Antropometri Anak. Jakarta: Kemenkes RI

8. Triwinarni, C., Hartini, T. dan Susilo, J. (2017). Hubungan Status Gizi dengan Kejadian Anemia Gizi Besi (AGB) pada Siswi SMA di Kecamatan Pakem. Jurnal Nutrisia. Vol. 19(1)

9. Awasthi, et al. (2016). Nutritional status of adolescent girls in urban slums of Moradabad. International Journal of Community Medicine and Public Health. Vol. 3(1):276-280. Department of Community Medicine, Teerthanker Mahaveer Medical College and Research Center, Teerthanker Mahaveer University, Moradabad, UP, India

10. Naelga, S., C. (2017). Nutritional Knowledge And Practices In Relation To The Nutritional Status Of The Secondary Students At Mindanao University Of Science And Technology, Mindanao, Philippines, 9000. The Turkish Online Journal of Design, Art, And Communication. Mindanao University Of Science And Technology.

11. Rohaeti, A., Tansah. (2015). Faktor-Faktor Yang Mempengaruhi Pengetahuan Gizi Pada Ibu Balita Gizi Buruk. Jurnal Obstretika Scientia. Vol 2(2)

12. Nurdzulqaidah,dkk. (2018). Hubungan Pengetahuan Gizi Seimbang dengan Perilaku Gizi Seimbang Mahasiswa Tingkat 4 Angkatan 2013 Fakultas Kedokteran Universitas Islam Bandung. Skripsi. Universitas Islam. Bandung

13. Shaziman, et al. (2017). Assessing Nutritional Knowledge, Attitudes And Practices And Body Mass Index Of Adolescent Residents Of Orphanage Institutions In Selangor And Malacca. Pakistan Journal Nutrition. Vol 16(6)

14. Al-Yateem, N., Dan Rossiter, R. (2017). Nutritional Knowledge And Habits Of Adolescents Aged 9 To 13 Years In Sharjah, United Arab Emirates. Eastern Mediterranean Health Journal. Vol. 23(8). University of Sharjah, Sharjah, United Arab Emirates

15. Arista, A. D., Widajanti d, L. dan Ruben, R. (2017). Hubungan Pengetahuan,Sikap,Tingkat Konsumsi Energi, Protein, Dan Indeks Massa Tubuh/Umur Dengan Kekurangan Energi Kronik Pada Remaja Putri (Studi Disekolah Menengah Kejuruan Islamic Centre Baiturrahman Semarang Pada Puasa Ramadhan Tahun 2017). Jurnal Kesehatan Masyarakat (E-Journal). Vol. 5(4). Fakultas Kesehatan Masyarakat. Universitas Diponegoro. Semarang

16. Rizkiyanti, Gandis. (2015). Status Hidrasi, Aktivitas Fisik Dan Tingkat Kebugaran Atlet Futsal Remaja Putrsi. Skripsi. Fakultas Ekologi Manusia. Institut Pertanian Bogor

17. Maharibe, C., Kawengian, S. dan Bolang, A. (2013). Hubungan Pengetahuan Gizi Seimbang Dengan Praktik Gizi Seimbang Mahasiswa Program Studi Pendidikan Dokter Angkatan 2013 Fakultas Kedokteran Universitas Sam Ratulangi. Ilmu Gizi Fakultas Kedokteran Universitas Sam Ratulangi. Manado. Jurnal e-Biomedik PAAI. Vol.2(1) 
18. Hayati, Nurul. (2014). Latar Belakang Tidak Meningkatnya Berat Badan Balita Setelah Mendapat Pemberian Makanan Tambahan Pemulihan (PMT-P) Di Wilayah Kerja Puskesmas Pamulang Tahun 2014. Skripsi. Program Studi Kesehatan Masyarakat. Fakultas Kedokteran Dan Ilmu Kesehatan. Uin Syarif Hidayatullah. Jakarta

19. Siburian, Agustina. (2016). Hubungan Pengetahuan Dan Sikap Gizi Seimbang Dengan Status Gizi Remaja Di SMA Negeri 3 Singingi Hilir Tahun 2016. Skripsi. Universitas Pahlawan Tuanku Tambusai

20. Salsabilla, Syafira. (2017). Hubungan Pengetahuan Gizi Dengan Sikap Mengkonsumsi Makanan Sehat Siswa SMK. Universitas Sarjana wiyata Taman siswa. Yogyakarta 